\title{
How To Create a Commercial Calamity
}

\author{
ROBERT A. HILLMAN ${ }^{*}$
}

This Article briefly catalogs the kinds of commercial calamities and then focuses on one of them, namely laws that are so imprecise and ambiguous that judges do not know how to apply them, and lawyers cannot explain them. The Article illustrates the problem with Uniform Commercial Code (UCC) section 2-209, dealing with contract modification and waiver. The paper does not focus on the ambiguities and obfuscations of section 2-209, but on the strategy of lawmaking that inevitably produces such a result. The drafters of section 2-209 ambitiously sought to reform the law, but then lost their nerve. In short, they wavered. The result was a compromise that created chaos, a true commercial calamity.

\section{INTRODUCTION}

There are many ways to define a legal calamity. For example, a grossly unfair or inefficient law constitutes a legal calamity. A law that produces serious and deleterious unintended effects, such as effects opposite from those intended, is another kind of legal calamity. ${ }^{l} \mathrm{~A}$ law that is so imprecise and confusing that judges do not know how to apply it and lawyers do not know how to advise their clients is still another example of a legal calamity, which I focus on here. Because this paper is a contribution to a symposium on commercial legal calamities, my example is Uniform Commercial Code (UCC) section 2-209, dealing with contract modification and waiver. But my goal is not to explain why 2-209 is a calamity of the third kind-everybody already knows that it is. ${ }^{2}$ I use the section to illustrate the kind of strategy of lawmaking that cannot fail to create a calamity of obfuscation. Section 2-209 illustrates what happens when lawmakers who boldly seek to reform the law cannot bring themselves to carry out their plan or never fully understand the ramifications of what they are doing. Instead, they waver. The result is chaos-a commercial calamity.

Part II briefly describes the operation of section 2-209 and inventories the

* Edwin Woodruff Professor of Law, Cornell Law School. I apologize for citing myself so often in this essay. In my defense, the topic of this symposium is "Commercial Calamities," in which participants were asked to write about their view of the worst aspect of commercial law. Topics that have occupied participants' attention for a long time, including in print, should therefore not be surprising. In addition, it is no secret that legal analysts enjoy citing themselves.

1 See Robert A. Hillman, The Rhetoric of Legal Backfire, 43 B.C. L. REV. 819 (2002) [hereinafter Hillman, Rhetoric].

2 See infra notes 4,28 , and accompanying text. 
myriad problems with the section. ${ }^{3}$ Part III focuses on some lessons we can learn about how to create (or avoid) a commercial calamity based on the experience of section 2-209. Part IV discusses the curious decision of the 1990s amenders of Article 2 ultimately to leave section 2-209 alone and sets forth some suggestions if another drafting committee ever revisits the issue.

\section{UCC SECTION 2-209}

Part II will be brief because analysts (including me) and judges already have thoroughly documented the infirmity of section 2-209.4 In short, the section was supposed "to simplify, clarify, and modernize the law governing" modification of contracts 5 but, instead, confused and set back the law. 6

Section 2-209(1) boldly terminates the long-standing common-law preexisting duty rule. 7 So far, so good. Prior to the subsection, under this rule, modifications of sales contracts required "fresh" consideration to be enforceable, meaning that a party could not be held to an agreed change of contract terms if that party did not bargain for and receive something new or different from the other party in exchange for the modification. But contracting parties frequently seek to adjust their terms midstream to account for changes in circumstances or changes of mind. Further, a party may agree to accommodate the other party without receiving more than an informal agreement from the latter to be flexible in the first party's time of need. ${ }^{8}$ The

${ }^{3}$ Part II draws on my previous writing on section 2-209. See, e.g., Robert A. Hillman, Standards for Revising Article 2 of the U.C.C.: The NOM Clause Model, 35 WM. \& MARY L. REV. 1509 (1994) [hereinafter Hillman, Standards]; Robert A. Hillman, Article 29(2) of the United Nations Convention on Contracts for the International Sale of Goods: A New Effort at Clarifying the Legal Effect of "No Oral Modification" Clauses, 21 CORNELL INT'L L.J. 449 (1988) [hereinafter Hillman, Article 29(2)]; Robert A. Hillman, A Study of Uniform Commercial Code Methodology: Contract Modification Under Article Two, 59 N.C. L. REV. 335 (1981) [hereinafter, Hillman, $A$ Study].

${ }^{4}$ See, e.g., Douglas K. Newell, Cleaning Up U.C.C. Section 2-209, 27 IDAHO L. REV. 487 (1990); Beth A. Eisler, Modification of Sales Contracts Under the Uniform Commercial Code: Section 2-209 Reconsidered, 57 TENN. L. REV. 401 (1990); Hillman, Standards, supra note 3; Hillman, Article 29(2), supra note 3; Wis. Knife Works v. Nat'l Metal Crafters, 781 F.2d 1280, 1284, 1290 (7th Cir. 1986) (Posner, J., in the majority and Easterbrook, J., in dissent).

5 U.C.C. $\S 1-102(2)(a)(2005)$.

${ }^{6}$ See infra notes 7-25, and accompanying text.

${ }^{7}$ UCC section 2-209(1) provides in full: "An agreement modifying a contract within this Article needs no consideration to be binding." U.C.C. § 2-209(1) (2005).

8 See Robert A. Hillman, Court Adjustment of Long-Term Contracts: An Analysis Under Modern Contract Law, 1987 DuKE L.J. 1 [hereinafter Hillman, Court Adjustment]; Newell, supra note 4, at 499 ("cooperation and good faith is expected"). 
preexisting duty rule stands in the way of such freely-made modifications and the drafters rightly extinguished the rule. In place of the rule, in an official comment, section 2-209 rules out "bad faith" modifications, ${ }^{9}$ meaning those modifications made under duress, such as when a party threatens not to perform without the modification when the other party is backed into a corner. ${ }^{10}$ In short, the drafters sought in section 2-209(1) to create an approach that facilitates the parties' efforts to adjust their agreements voluntarily, while ruling out bad-faith modifications.

Lon Fuller long ago offered the most comprehensive explanation for the requirement of consideration to support the enforcement of contract promises. ${ }^{11} \mathrm{He}$ posited, in part, that the consideration requirement cautions the parties about the seriousness of their undertaking and provides evidence that the parties made a contract. ${ }^{12}$ The drafters of section 2-209 must have worried that by eliminating the consideration requirement in the modification context these safeguards would be lost. They therefore backtracked in section 2-209(2) by reversing another long-standing common-law approach. Prior to this subsection, courts generally declined to enforce no-oral-modification clauses (NOM clauses), which, true to their name, constituted a private statute of frauds between the parties. ${ }^{13}$ Courts reasoned that parties should be free to change their minds about requiring written modifications, and therefore enforced oral modifications notwithstanding a NOM clause. ${ }^{14}$ Section 2-209(2), however, makes NOM clauses enforceable on the theory that parties should be free to protect themselves from "inconsiderate action" 15 or fraudulent assertions of oral modification.

Consistent with their reliance on writing requirements to satisfy Fuller's cautionary and evidentiary functions, the drafters added section 2-209(3), under which a modification must satisfy the general statute of frauds in Section 2-201 "if the contract as modified is within its provisions." 16 Unfortunately, the language of section 2-209(3) is not precise, perhaps a by-product of the drafters' ambivalence about regulating freely-made

${ }^{9}$ U.C.C. $§ 2-209 \mathrm{cmt} .2$ (2005).

10 Robert A. Hillman, Policing Contract Modifications Under the U.C.C.: Good Faith and the Doctrine of Economic Duress, 64 IowA L. REv. 849 (1979).

${ }^{11}$ Lon L. Fuller, Consideration and Form, 41 CoLUM. L. REV. 799 (1941).

12 Id. at $800-01$.

${ }^{13}$ Hillman, Article 29(2), supra note 3, at 453.

14 Id.

15 Fuller, supra note 11 , at 800.

16 U.C.C. $\$ 2-209$ (3) (2005) (The provision states in full: "The requirements of the statute of frauds section of this article (section 2-201) must be satisfied if the contract as modified is within its provisions."). 
modifications at all. For example, does the language calling for satisfaction of section 2-201 "if the contract as modified is within its provisions" mean that section 2-201 must be satisfied if the total contract price after the modification is greater than $\$ 500$ or if the modification itself is greater than $\$ 500$ ? Alternatively, perhaps the language requires a written modification if the modification brings the total value of the contract to greater than $\$ 500$ for the first time. ${ }^{17}$

But, alas, the drafters flip-flopped once again in section 2-209(4). The drafters must have realized that their recognition of NOM clauses in section 2-209(2) and their invocation of the general statute of frauds in section $2-209$ (3) would stand in the way of lots of voluntary oral adjustments to contracts. Further, they must have thought that a good argument could be made that freedom of contract means that parties should be free to change their minds, not only about terms, but about their agreed process of adjustment. ${ }^{18}$ As a result, the drafters provided in subsection (4) that an "attempt" at modifying an agreement "can operate as a waiver" despite the presence of a NOM clause or the statutory writing requirement. ${ }^{19}$ This weird "attempt at modification" and "can operate as a waiver" language creates lots of ambiguities too. For example, what precisely is an "attempt at modification?" It must mean something short of a signed written modification because that would satisfy section 2-209(2). But does an "attempt at modification" require an oral agreement, a unilateral waiver, or some kind of estoppel? ${ }^{20}$ And what exactly is the significance of something "operating" as a waiver? For that matter, what kind of waiver did the drafters have in mind?21 The larger question, of course, is, after section 2-209(4), what is left of sections 2-209(2) and (3) and the joint goals of protecting parties from incaution and fraudulent oral claims of modification? Not much.

But the drafters were still not finished with their own wavering. Perhaps they believed they went too far in section 2-209(4) by enforcing waivers, and thought they had to corral them in section 2-209(5). Under this subsection, a party can retract a waiver unless retraction would be "unjust" because the

17 See Hillman, A Study, supra note 3, at 359.

${ }^{18}$ Hillman, Article 29(2), supra note 3, at 451.

19 U.C.C. $§ 2-209$ (4) (2005) (The provision states in full: "Although an attempt at modification or rescission does not satisfy the requirements of subsection (2) or (3), it can operate as a waiver.").

${ }^{20}$ See Hillman, Article 29(2), supra note 3, at 454. In addition, "although the Code states that an 'attempt at modification ... can operate as a waiver,' it fails to explain when it does so operate." Id.

${ }^{21}$ Hillman, A Study, supra note 3, at 364-70. 
other party has materially relied on it. ${ }^{22}$ The subsection raises new questions-what constitutes an injustice and when is reliance "material?"23 But at least the subsection may shed some light on what the drafters meant by their "can operate as a waiver" language in subsection 2-209(4). Perhaps an oral modification in the face of a writing requirement "can operate as a waiver" only when a party has materially relied on it. ${ }^{24}$

Section 2-209 is a calamity because it tries to facilitate commercial parties' transactions but, instead, creates confusion and uncertainty. ${ }^{25}$ What does this section tell us more generally about how to create (and therefore how to avoid) commercial calamities of this nature? That is the subject of Part III.

\section{HOW TO CREATE A COMMERCIAL CALAMITY - LESSONS FROM SECTION 2-209}

Needless to say, many factors may have contributed to the calamity of section 2-209. For example, perhaps the influence of interest groups or disagreement among drafting committee members contributed to the ambivalence of the drafters and led to some ill-advised drafting decisions. ${ }^{26}$

22 U.C.C. § 2-209(5) (2005) ("A party who has made a waiver affecting an executory portion of the contract may retract the waiver by reasonable notification received by the other party that strict performance will be required of any term waived, unless the retraction would be unjust in view of a material change of position in reliance on the waiver.").

${ }^{23}$ Hillman, Article 29(2), supra note 3, at 454.

24 This was the approach of Judge Posner in Wisconsin Knife Works v. National Metal Crafters. Wis. Knife Works v. Nat'l Metal Crafters, 781 F.2d 1280, 1287 (7th Cir. 1986). Judge Easterbrook dissented because nothing in section 2-209(4) indicates that reliance is required: "Under $\$ 2-209(4)$ a waiver may be effective; under $\S 2-209(5)$ a waiver may be effective prospectively only if there was also detrimental reliance." Id. at 1291.

25 "[T] 2-209 is complex, not simple; murky, not clear; and, with the exception of subsection (1), antiquated, not modern." Newell, supra note 4, at 487-89; see also Eisler, supra note 4, at 401 (noting that "factual and legal issues associated with section 2-209 have led to extensive litigation").

${ }^{26}$ I do not think that politics were a principal reason for section 2-209's problems, although some see a pervasive political influence on the content of contract law. For example, some writers in the 1990s detected a "new conservatism" in judicial decisions applying contract law that constituted a "judicial tilt away from underdogs, back toward the privileged beneficiaries of classical contract law." Ralph J. Mooney, The New Conceptualism in Contract Law, 74 OR. L. REV. 1131, 1170-71 (1995). This new conservatism was supposed to favor a formal, rule-oriented approach to contract law that avoided the equities of the case at hand. See Robert A. Hillman, The "New Conservatism" in Contract Law and the Process of Legal Change, 40 B.C. L. REV. 879, 879-80 (1999) (evaluating the existence of a "new conservatism"). Because section 2-209 exhibits both 
But I do not intend to canvass these or other related possible reasons for the failure of section 2-209, to dig into the legislative history of the section, or to rehash more generally the rich literature assessing the many hurdles to effective lawmaking. ${ }^{27} \mathrm{I}$ believe there are fundamental reasons for the calamity of section 2-209 that are apparent on the face of the section. In short, on its face, the section is an instructional manual on how to go about creating a commercial calamity.

I will discuss three strategies illustrated by section 2-209 that, when combined, are sure-fire calamity-producers. One is obvious from the discussion in Part II: Draft a law that flip-flops on what it is trying to achieve. A second related calamity-producing strategy, which helps explain the flip-flopping, is also not much of a revelation: Draft a law without having a good idea of its effects. A third, perhaps less obvious, strategy, also helpful in explaining the drafters' ambivalence, is to draft a law without resolving the meaning in the particular context of foundational principles (here, freedom of contract, fairness, and efficiency). Drafters who engage in these strategies of lawmaking can be quite confident that they will have created a legal calamity.

\section{A. Flip-flopping}

Part II of this essay revisits the efforts of the drafters of section 2-209 to create rules supporting informality in contract modification while, at the same time, guaranteeing contractual security. Briefly rehashing, the drafters' first foray was to abolish the requirement of consideration to enforce a modification. Uncomfortable with the loss of this formal requirement for enforcement of modifications, however, they then overturned another long-standing rule, namely by making NOM clauses enforceable, and they reinforced the public statute of frauds in the modification setting. Next, they thought better of this set of moves in light of the frequency of oral modifications, so they elevated the common-law waiver principle to statutory status. But then they realized that not every "attempt at modification" should be treated as a waiver or else there would be nothing left of the private and public statute of frauds. By this time they were sufficiently worn down, so they decided to leave to courts the decision as to precisely when the law should treat a modification as "operating" as a waiver. Finally, the drafters narrowed the waiver still further by allowing for its retraction until a party relies on it.

The term "schizophrenic" has been used more than once to describe this

formal and flexible leanings, either politics was not at work in the drafting of section 2-209 or the drafters listened to everybody.

27 See, e.g., sources cited in Hillman, Rhetoric, supra note 1. 
mindset of the drafters. ${ }^{28}$ The drafters' inability to find the proper balance between the competing instrumental concerns of facilitating adjustment and transactional security, as reflected in their section 2-209 end-product, hardly creates confidence that interpreters of the law can find the balance for them. In short, flip-flopping is not a recommended technique for simplifying, clarifying, and modernizing the law, and commercial transactors, lawyers, and judges have paid the price. ${ }^{29}$

What accounts for the drafters' waffling? I turn to an explanation in the next subsection, which itself presents another key ingredient in creating a commercial calamity.

\section{B. Marching Forward in the Face of Instrumental Uncertainty}

Prescribing legal rules for society's problems is an inexact science. Just as medical doctors often prescribe medicine on a trial-and-error basis, seeking to find the appropriate remedy for what ails the patient, lawmakers sometimes draft legal rules with hope but little assurance that the particular palliative will produce the appropriate outcome. An important reason for this strategy is that empirical studies of legal issues and solutions are difficult, time-consuming, often inconclusive, and still uncommon..$^{30}$ Further, most empirical work that is accomplished studies existing laws, exacerbating the lawmaker's dilemma when setting forth down a relatively novel path. ${ }^{31}$ Obviously, lawmaking is most problematic when lawmakers must decide based on theory, anecdotes, and conjecture.

28 Newell, supra note 4, at 489; David V. Snyder, The Law of Contract and the Concept of Change: Public and Private Attempts to Regulate Modification, Waiver, and Estoppel, 1999 WIS. L. REV. 607, 646.

29 "Fudging," a first-cousin of flip-flopping, also is not recommended. See Arthur A. Leff, Unconscionability and the Code-The Emperor's New Clause, 115 U. PA. L. REV. 485, 498-501 (1967) (discussing ambiguity created by drafters' fudging); Newell, supra note 4, at 494 ("Pity the average lawyer or judge confronting" section 2-209.); Eisler, supra note 4 , at 403 (stating that "judges and commentators have been unable to reach a consensus concerning the correct interpretation of section 2-209").

30 See, e.g., Cass R. Sunstein, Paradoxes of the Regulatory State, 57 U. CHI. L. REV. 407,409 (1990) ("[E]mpirical assessments of the consequences of regulation remain in a primitive state ....”); Lisa Heinzerling, Regulatory Costs of Mythic Proportions, 107 YALE L.J. 1981, 1986 (1998) (occasional empirical study given too much weight). Hillman, Rhetoric, supra note 1, at 840-45. However, the theme of the 2006 American Association of Law Schools' annual convention, Empirical Scholarship, What Should We Study and How Should We Study It?, evidences a movement to increase and improve empirical studies of the law.

31 See John Monahan \& Laurens Walker, Empirical Questions Without Empirical Answers, 1991 WIS. L. REV. 569. 
Apparently without reliable empirical evidence of actual business practices, or even educated predictions on how the rule changes would affect business, the drafters decided to reverse two long-standing common-law rules, elevate the waiver principle to statutory status, and broaden the reach of the statute of frauds, all in the name of "simplify[ing], clarify[ing], and moderniz[ing]" the law of contract modification. ${ }^{32}$ As already noted, the drafters were concerned about the loss of the cautionary function of consideration, but they refused to be cautioned themselves by the lack of empirical evidence of the effects of their work. In fact, instead of slowing them down, the drafters' apparent lack of knowledge of the upshot of their concoction appears to have spurred them on to experiment by putting a little bit of this and a little bit of that in their product.

Of course, most theorists and lawyers at that time probably agreed with the drafters' move to eliminate the preexisting duty rule, and I doubt that we could find anyone today who would defend the rule in its pristine form. ${ }^{33}$ But the drafters went much further, presumably because they believed that their package of NOM clauses, the general statute of frauds, and waivers would more often benefit the parties affected than hurt them. In truth, however, the drafters had little way of knowing whether the net benefit of these "reforms" would outweigh their net costs, even assuming they had been able to achieve the changes with clarity and precision. What seems apparent is that the package of reforms as written has through obfuscation dramatically increased the cost side of the ledger.

What does this suggest about creating or avoiding a commercial calamity? Perhaps the drafters should have tried to do less in section $2-209$, just as a doctor should resist prescribing multiple medicines for a patient without an understanding of their cumulative effect. Unsure of the payoff of their ambitious restructuring of modification law, they should have opted for a more

32 U.C.C. § 1-102(2)(b) (2005).

33 The Restatement (Second) of Contracts carries over the preexisting duty rule but with several exceptions. See RESTATEMENT (SECOND) OF CONTRACTS $\S 89$ (1981).

In an interesting series of articles, Omri Ben Shahar and Oren Bar-Gill criticize the judicial approach to policing contract modifications. See Oren Bar-Gill \& Omri Ben-Shahar, The Law of Duress and the Economics of Credible Threats, 33 J. LEGAL STUD. 391 (2004), Oren Bar-Gill \& Omri Ben-Shahar, Threatening an "Irrational" Breach of Contract, 11 SUP. CT. ECON. REV. 143 (2004). They claim that the only factor for determining modification enforcement should be the "credibility" of the threat of the breaching party not to perform. This has implications for section 2-209's admonition to police modifications using the standard of good faith, which courts generally interpret to mean reasonable and honest behavior. Although the authors do not seek to turn the clock back to the enforcement of the preexisting duty rule, they are not content with section $2-209$, at least as courts interpret it. 
modest approach. Of course, lawmaking is time-consuming and costly, and lawmakers do not have the luxury of excessive experimentation, especially in drafting a Code that they hoped would be uniform legislation in each of the states. Still, when faced with the choice of doing a lot or a little in the face of uncertainty, the lesson of section 2-209 appears to be to choose the latter. I will have more to say about what the drafters should have done in Part IV.

\section{Drafting in the Face of the Indeterminacy of Foundational Principles}

Here I focus on the drafters' waffling over NOM clauses, making them enforceable in subsection (2), and retreating by recognizing waivers in subsection (4). Part of the reason for the drafters' schizophrenia must have stemmed from their failure to take a position on the meaning of freedom of contract, efficiency, and fairness in this setting. ${ }^{34}$ Parties draft a NOM clause because, at the time of contracting, they believe that the benefits of certainty and stability outweigh the loss of flexibility in adjusting their contract. ${ }^{35}$ Arguably, the state should support this goal to protect the parties from their own subsequent "weakness of will."36 Even if the parties' balancing of gains and losses from using NOM clauses is mistaken, freedom of contract still arguably commands the state to enforce their wishes.

As for the efficiency of enforcing NOM clauses, I have previously written:

[E]nforcement [of a NOM clause] appears to be efficient if the parties, in theory the best judges of their needs and interests, believed at the time of contracting that the gains in certainty and stability of including a NOM clause would outweigh the costs of greater formality. Denying enforcement of NOM clauses would be based on the paternalistic assumption that the [state's] judgment of the value of NOM clauses is better than the parties'. ${ }^{37}$

On the other hand, a good case can be made that enforcing NOM clauses impedes freedom of contract because parties should be free to change their minds about any aspect of their contract, including a term that bars oral

34 See Hillman, Article 29(2), supra note 3, at 452 ("Arguments appealing to freedom .... are inherently controversial. Philosophers and legal scholars have long wrestled with the question of what constitutes individual and contractual freedom ....").

35 See Guido Calabresi \& A. Douglas Melamed, Property Rules, Liability Rules, and Inalienability, One View of the Cathedral, 85 HARV. L. REV. 1089, 1113 (1972); Hillman, Article 29(2), supra note 3, at 450.

36 See JON ELSTER, UlySSES AND THE SIRENS 37 (2000) ("[B]inding oneself is a privileged way of resolving the problem of weakness of will; the main technique for achieving rationality by indirect means.").

${ }^{37}$ Hillman, Standards, supra note 3, at 1527. 
modification. ${ }^{38}$ Perhaps efficiency requires enforcement of the parties' latest manifestation of their intent as well. ${ }^{39}$

Fairness principles also seem unhelpful in the context of modification law. On the one hand, fairness may dictate that parties should not be rewarded for ignoring a term of their written agreement, specifically by enforcing an oral modification in the face of a NOM clause. ${ }^{40}$ On the other, if a party reasonably relied on an oral modification, fairness may require enforcement of the modification or at least compensation for the reliance loss. ${ }^{41}$ Of course, the question of whether reliance is reasonable and foreseeable and therefore a good basis for enforcing an oral modification on fairness grounds depends on the context and, specifically, the parties' own view of the utility of their NOM clause. ${ }^{42}$ These are very case-specific issues.

In the absence of legal norms sending clear signals as to the appropriate legal framework; and without fairly reliable indications of the instrumental effects of their work, the drafters were left to sink or swim based on their own intuitions. Instead of trying to choose among clear alternatives, they waffled.

\section{REVISED ARTICLE 2-209 AND OTHER SOLUTIONS}

\section{A. Revised Article 2-209}

Beginning in the 1990s and into the new millennium, a drafting committee of the National Conference of Commissioners on Uniform State Laws and the American Law Institute labored on revising Article 2. Their efforts began as a major overhaul in which they combined as subject matter goods and information, which subsequently morphed into the creation of a new model law on information (Uniform Computer Information Transactions Act) and a separate revision of Article 2, which itself later became simply amendments to Article $2 .{ }^{43}$ Much has already been written about the reasons for the ups and downs of that process, which I won't repeat here. ${ }^{44}$ Instead, I focus on what happened to section 2-209 during that process. Although several interim drafts

38 Hillman, Article 29(2), supra note 3, at 451.

39 Hillman, Standards, supra note 3, at 1527.

40 Hillman, Article 29(2), supra note 3, at 465.

$41 \mathrm{Id}$.

42 See infra note 56, and accompanying text.

${ }^{43}$ For more history, see Linda J. Rusch, A History and Perspective of Revised Article 2: The Never Ending Saga of a Search for Balance, 52 SMU L. REV. 1683 (1999).

${ }^{44}$ See, e.g., id. I attended many of the drafting committee meetings as a consultant for the American Automobile Manufacturers Association. The car companies were mainly interested in their rights as buyers of component parts. 
evidenced attempts at clarifying the section, the section was virtually intact in the end-product. Does this suggest that I am wrong about section 2-209 being a commercial calamity? After all, the drafters had more than ten years to think about changes and ultimately left section 2-209 alone. I think the progression of drafts shows otherwise. The drafters simply did not have more to go on than the drafters of the original product concerning instrumental effects and normative direction, and therefore limited themselves to tinkering with the section before ultimately concluding that it would be preferable to leave a calamity well enough alone. What follows is a brief sample of the progression of drafts.

Although many drafts preceded the 1996 draft, I pick up the story there. ${ }^{45}$ The March draft of that year on modification reiterated in subsection (a) of what was then section 2-210 that modifications were enforceable without consideration, but elevated the obligation of good faith from a comment to the text. ${ }^{46}$ Subsection (b) enforced NOM clauses except in the case of consumer

45 For the previous history, see Hillman, Standards, supra note 3, at 1529-32.

46 The full text of the treatment of contract modification in the March 1996 draft reads:

SECTION 2-210. MODIFICATION, RESCISSION, AND WAIVER.

(a) A good-faith agreement modifying a contract under this [article] is binding without consideration.

(b) Except in a consumer contract or as otherwise provided in subsection (c), a contract that contains a term prohibiting modification or rescission except by a signed record may not be otherwise modified or rescinded.

(c) A party whose language or conduct in modifying or rescinding a contract is inconsistent with a term requiring a signed record to modify or rescind a contract may not assert the term if the other party is induced to change its position reasonably and in good faith.

(d) Subject to subsection (c), a contract term may be modified or rescinded by waiver. Language or a course of performance between the parties is relevant to show a waiver of any term inconsistent with that language or course of performance. The waiver of an executory portion of the contract may be retracted by reasonable notification received by the other party that strict performance is required of any term waived unless the waiver induced the other party to change its position reasonably and in good faith.

SOURCE: Sales, Section 2-209 (Dec., 1994)

U.C.C. § 2-209 Mar. 1996 Draft (on file with author). 
contracts. The drafters did not explain the consumer exception, but they must have believed that any private statute of frauds hurt consumers more than helped them. Section 2-210 did not refer to the general statute of frauds at all because by 1996 the drafters had deleted it from Article 2. Subsection (c) preserved the possibility of oral modifications of business contracts notwithstanding a NOM clause when one party "reasonably and in good faith" relied on the other party's "language or conduct" inconsistent with the need for a written modification. ${ }^{47}$ Although subsection (c) made no effort to reconcile the schizophrenia of enforcing NOM clauses and permitting their waiver, the subsection arguably was an improvement because it focused on whether a party induced the other party reasonably to rely to its detriment. Subsection (d) recognized waivers of substantive terms in situations where the parties did not include a NOM clause.

The drafters restored the general statute of frauds in the modification setting in the January 1997 draft because, by this time, they had decided to reintroduce the general statute of frauds of section 2-201. ${ }^{48}$ The revisers attempted to clarify precisely when a modification must be in writing, but the effort was short-lived. ${ }^{49}$ The revisers left most of the rest of the $1996 \mathrm{draft}$ on modification substantially intact through March 1999.

The March 1999 draft of what was now again section 2-209 made modification enforcement subject to section 2-207 (dealing with the battle of the forms) as well as good faith. ${ }^{50}$ Further, the drafters dropped from the text the requirement of reasonable and good faith reliance before an oral modification was enforceable notwithstanding a private statute of frauds. Instead, the test was whether enforcement of the writing requirement would be "unjust" in light of the reliance. 51

47 Current section 2-209(4) has been criticized for failing to clarify whether a party must waive the NOM clause or the term being modified or both. But in reality, any time parties seek to change a term orally in the face of a NOM clause, they must be contemplating doing both.

48 Subsection (b) in the January 1997 draft stated: "If the agreement modifying the contract or the contract as modified are [sic] within Section 2-201, the requirements of the statute of frauds must be satisfied." U.C.C. § 2-201 Jan. 1997 Draft (on file with author).

49 The drafters must have been unhappy with subsection (b) because they deleted it entirely in the March 1998 draft, explaining as a consequence that "it is clear that if the original agreement satisfies the statute the modification is enforceable even though it is within the statute and does not comply." U.C.C. § 2-209 Mar. 1998 Draft, Note 2 (on file with author).

50 Section 2-209(a) provided: "Subject to Section 2-207, an agreement made in good faith modifying a contract under this article needs no consideration to be binding." U.C.C. § 2-209(a) March 1999 Draft (on file with author).

51 Section 2-209(b) of the March 2000 draft provided in part: "A party whose 
Up to this point, apart from a lot of tinkering only in part described above, the drafters had failed to come to terms with the threshold issue of section 2-209-precisely when writing requirements for modifications should be enforced. In addition, by March 2000, even the tinkering had disappeared. Section 2-209(a) no longer expressly required good faith. In addition, subsection (d) closely resembled current section 2-209(4), except for clarifying that an "attempt at modification ... can operate as a waiver" of the general or NOM statute of frauds. ${ }^{52}$ With little or no empirical evidence of how businesses adjust their contracts, uncertainty about the legal effect of the existing treatment of modifications, and little contemplation of the meaning of freedom of contract, efficiency, or fairness in this context, the revisers unsurprisingly failed to improve or even change the law of contract modification.

\section{B. Guidance for Future Drafters}

The discussion above does not address the question of what, if anything, a new set of drafters should try to accomplish, assuming Article 2 again becomes the subject of revision. Having called current section 2-209 a calamity, I can hardly claim that new drafters should leave the section alone. Instead, I would ask them to consider seriously taking a clear position on the role, if any, of writing requirements in the modification setting. This would require gathering evidence of whether the costs of writing requirements in impeding freely made oral modifications exceed the benefits in cautioning parties and proving the existence of modifications..$^{53} \mathrm{My}$ strong hunch is that the drafters will learn that business parties so frequently rely on oral modifications that writing requirements do more harm than good. ${ }^{54}$ If so, the drafters should abolish them. Such an approach would clarify the law and promote a uniform interpretation of section 2-209. Further, the strategy would

language or conduct is inconsistent with the [NOM clause] is precluded from asserting the term if the assertion is unjust in view of a material change of position in reliance on the language or conduct." U.C.C. $\S 2-209$ (b) March 2000 Draft (on file with author).

52 Subsection (d) of the March 2000 draft provided: "Although an attempt at modification or rescission does not satisfy the requirements of subsection (b) or (c) it can operate as a waiver of those requirements." U.C.C. $\S 2-209$ (d) March 2000 Draft (on file with author)..

53 Hillman, Article 29(2), supra note 3, at 463. But I am a realist about the practicalities of accomplishing reliable studies in the context of the drafting experience. I expect that the most the drafters can do is to compile some evidence by talking to various transactors likely to be affected by the legislation (and not just interest groups attending the drafting committee meetings).

${ }^{54}$ Hillman, Court Adjustment, supra note 8. 
end the stalemate over whether parties should be free to bind themselves to written modifications or should be free to change their minds, even about the process of amending their contracts. ${ }^{55}$

If new drafters insist on a compromise, I would ask them to offer more guidance on when an oral modification should survive a writing requirement. ${ }^{56}$ Specifically, I would suggest that section 2-209 direct courts to focus on the parties' course of dealing and customs in the particular industry. In situations where parties transact business informally and flexibly, orally adjust their agreement as circumstances change, and rarely rely on their written contract, oral modifications should be enforceable. Chances are that these parties are unaware of, or wish to override, any boilerplate NOM clause that may be in the contract or any general statute of frauds. Further, reliance on oral modifications in this context is reasonable and, because the parties prefer informality, enforcement of oral adjustments is probably fair and efficient. On the other hand, if the custom in the industry is for parties to rely heavily on written terms or if parties invest significant resources drafting their initial contract, including the NOM clause, frequently consult the written terms in carrying out their agreement, and fail to establish a practice of oral adjustment, a public or private statute of frauds should be enforced.

\section{CONCLUSION}

Section 2-209 is a commercial calamity of obfuscation, but we can learn from it. Drafters should not try to accommodate conflicting positions when the result is confusion. Further, drafters should try to collect evidence of real-world transactions and the likely effects of proposed rules. Finally, drafters should not introduce broad standards that lead in opposite directions or in no clear direction.

55 of course, enforcing NOM clauses and not waivers would also end the controversy over the meaning of freedom of contract in this context.

56 See generally, Hillman, Article 29(2), supra note 3, at 464-660. 